\title{
Pembuatan Iklan Game Berbasis Instagram
}

\author{
Agnes Renica Irwan*, Riwinoto** \\ Program Studi Teknik Multimedia dan Jaringan, Jurusan Teknik Informatika \\ Politeknik Negeri Batam \\ renicaagnes@gmail.com
}

\begin{abstract}
Article Info
Article history:

Received Sept $12^{\text {th }}, 2021$

Revised Nov 20, 2021

Accepted Nov 26 ${ }^{\text {th }}, 2021$

\section{Keyword:}

Instagram

Advertising Media

Game Ads

Insight

Float Indonesia

Epic Model

ABSTRACT

Current developments have made online media or social media a platform that is widely used and in demand, and there have been many uses of social media such as Instagram for advertising or promotion. To promote products, among others, game ads "Bisa Jadi" are products that will be advertised on the Instagram social media platform in the form of video game ads. The game "Bisa Jadi" is a puzzle game where the player aims to guess the instructions and rules of the game. And the main purpose of making this game ad is to introduce or promote games made by the Indonesian Float Game company. Instagram is considered the right place to promote products in the form of advertisements and Instagram-based game ads. In Instagram there are also various kinds of features, and the features used in advertising the "Bisa Jadi" game use the Instagram Story,
\end{abstract}

\section{LATAR BELAKANG}

Dalam perkembangan zaman sekarang. Perkembangan teknologi informasi memberikan kontribusi nyata terhadap perkembangan media dalam bentuk maupun sajian informasinya yang sekaligus juga memberikan dampak pada khalayak dalam mengaksesnya. Perkembangan teknologi yang demikian pesat itu juga merambah industri media. Media digital menjadi media yang sedang popular dalam beberapa tahun terakhir. Dan di zaman sekarang sudah banyak media yang berkembang dalam media Iklan, baik secara online ataupun media cetak. Media online adalah salah satu media yang banyak peminat dan pengaruhnya. Salah satu media online yang dapat dijadikan media Iklan adalah platform Instagram.

Menurut Bambang, Instagram itu sendiri merupakan sebuah aplikasi dari smartphone khusus untuk media sosial dan merupakan salah satu media digital dengan mempunyai fungsi hampir sama dengan platform media sosial twitter, dengan perbedaan yang terletak pada pengambilan video. Selain itu Instagram juga dapat dijadikan media Iklan, seperti promosi iklan produk, dalam bentuk video ataupun foto. Fitur fitur yang ada di Instagram dapat digunakan bukan hanya sekedar menjadi media sosial. Dalam bidang pendidikan Instagram juga dapat berperan sebagai sosial media yang dapat digunakan untuk berbagi ilmu pengetahuan dalam bentuk video ataupun foto. Dalam penelitian ini Instagram digunakan untuk melihat seberapa berpengaruhnya efektivitas Instagram dalam media promosi Iklan online.

Untuk mempromosikan produk, antara lain iklan game adalah produk yang akan diklankan di platform sosial media Instagram dalam bentuk video Iklan game. Game Menurut Greg Costikyan merupakan bentuk karya seni di mana peserta, yang disebut pemain, membuat keputusan untuk mengelola sumber daya yang dimilikinya melalui benda di dalam game demi mencapai tujuan. Dan tujuan membuat video iklan di tugas akhir ini adalah memperkenalkan game hasil karya Float Indonesia oleh mahasiswa magang di Float Indonesia dengan game yang bernama Game "Bisa Jadi".

Video akan di upload di dua fitur Instagram itu sendiri, video pertama yang berdurasi satu menit akan dipublikasikan di Instagram feed dan video yang berdurasi 3 menit akan dipublikasikan di fitur Instagram Tv. Dengan tahapan publikasi video di Instagram terbagi lagi menjadi Instagram story, Instagram feed, Instagram Tv dan Youtube. Setelah Iklan Game "Bisa Jadi" dipublikasikan, maka akan dilakukan analisis dan penelitian dengan menggunakan EPIC model untuk melihat hasil perhitungan dan ke efektifitas Iklan 


\section{TINJAUAN PUSTAKA}

Analisis pada user interface sebuah game atau aplikasi sudah cukup banyak dibuat. Hal tersebut pula dapat dijadikan sebagai referensi untuk mengidentifikasi penelitiaan ini agar dapat dibedakan dengan penelitian lainnyaa. Berikut beberapa penelitian terdahulu yang digunakan sebagai referensi penelitian ini :

Mochammad amirul hakim (2014) melakukan penelitian mengenai perancangan iklan gim mobile activia sebagai media periklanan android dengan metode Research and developmet, tujuan dari penelitian ini untuk medio promosi gim pada platform android.

Penelitian selanjutnya bersumber dari Finorita eka sari (2015) melakukan penelitian pembuatan video iklan televisi iphone $5 \mathrm{~s}$ touch id, identity sensor dengan menggabungkan video real life dan animasi 3d, dengan menggunakan metode Analisis Swot dan tujuan dari penelitian ini dalam perancangan video televisi dan untuk memperkenalkan video dalam bentuk iklan.

Penelitian selanjutnya dari Henni Aprilia Sari (2018) melakukan penelitian pengaruh iklan media social Instagram terhadap respon konsumen menggunakan metode Research and development, tujuan dari penelitian yang dilakukan Henni Aprilia Sari (2018) ini adalah untuk melihat pengaruh positi dari iklan media social Instagram.

2.1. Media Iklan

Pada saat ini sudah banyak jenis iklan dan saat ini juga terdapat iklan yang dikategorikan sebagai iklan media, yaitu iklan tentang media itu sendiri. Munculnya iklan media disebabkan karena ditengah masyarakat terjadi persaingan media yang sangat ketat, media pada akhirnya juga membutuhkan untuk mengiklankan produk, sehingga isi produk atau artikelnya diketahui oleh khlayak. Target khalayak iklan ini selain masyarakat, juga para calon pengiklan. Kiranya masih banyak lagi kategori iklan lainnya berdasar isi pesan iklan. Jumlah iklan berdasar kategori isi pesan akan sangat banyak, sebanyak jumlah isi pesan itu sendiri. Anda dapat mengelompokkan berbagai iklan yang lain.

2.2. Video

Video adalah rekaman gambar hidup atau tayangan gambar bergerak yang disertai suara. Munir mengatakan video merupakan teknologi penangkapan, perekaman, pengolahan, penyimpanan, pemindahan, dan perekonstruksian urutan gambar yang diam dengan menyajikan adegan-adegan dalam gerak secara digital. Munadi (2008) menyatakan bahwa video merupakan sebuah teknologi pemrosesan sinyal elektronik meliputi gambar, gerak, dan suara.

2.3. Game Bisa Jadi

Game Bisa Jadi adalah game buatan mahasiswa magang di Float Indonesia. Game ini adalah game yang berjenis Teka-Teki atau menebak kata. Game Bisa Jadi ter-inspirasi oleh permainan eat bulaga. Yaitu permainan menebak kata dengan clue, pada permainan nya terdapat dua orang yang saling berhadapan, satu orang yang akan menebak kata dan satu orang akan menjawab ya atau tidak sesuai dengan clue yang di tebak sampai jawaban benar. Pada Game Bisa Jadi diterapkan game dengan mode menebak clue dengan mengetik jawaban oleh player, dan pada layar akan ada animasi orang yang menjadi npc yang akan menjawab.

2.4. EPIC Model

Penelitian tentang Efektivitas Jejaring sosial telah banyak dilakukan oleh peneliti Indonesia. Model yang digunakan peneliti bervariasi. Durianto [1], menyebutkan bahwa terdapat beberapa metode yang dapat digunakan untuk melihat efektifitas suatu iklan berdasarkan dampak komunikasi yang ditimbulkan, yaitu: CRI (Customer Response Index), DRM (Direct Rating Method), EPIC Model, dan CDM (Consumer Decision Model). Efektivitas sebuah media Iklan online dapat diukur melalui EPIC Model. Nielsen merupakan sebuah perusahaan yang bergerak dibidang informasi global serta media peneliti pemasaran terkemuka di dunia yang mengukur empat dimensi kritis, yakni: empati, persuasi, dampak dan komunikasi (Empathy, Persuation, Impact dan Communication)

2.5. Villamil Molina

Metode Villamil-Molina adalah metode dalan bentuk pengembangan multimedia. Metode ini akan berhasil dengan baik jika menggunakan perencanaan yang teliti, penguasaan teknologi multimedia yang baik, serta penguasaan manajemen produksi yang baik. Dalam metode ini tahapan yang akan dikerjakan berikutnya dapat dikerjakan apabila tahapan pengerjaan sebelumnya telah selesai dikerjakan 
3. METODE PENELITIAN

Metode pengembangan Villamil-Molina digunakan pada penelitian ini untuk membuat produk video iklan game sebelum menjadi Iklan game yang akan di iklan kan di Instagram. Model pengembangan ini terdiri dari 5 tahapan yaitu tahap development, pra production, production, post production, dan delivery. Tahap satu dan dua diuraikan pada bab III yaitu development dan pra production, sedangkan production, post production, dan delivery akan diuraikan pada bab IV.

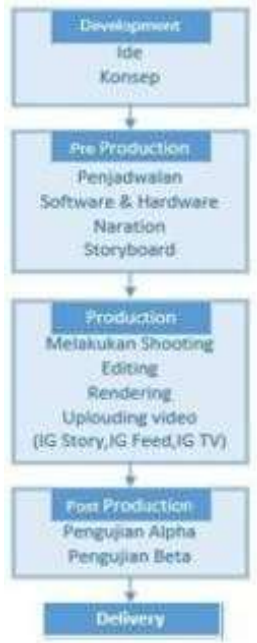

Gambar 1. Metode Perancangan Villamil Molina

Analisis yang dilakukan untuk melihat efektif dari iklan game di instagram dengan pengujian media analysis lalu teknik pengumpulan data menggunakan metode EPIC Model menggunakan kuesioner dan hasil dari kuesioner akan dihitung menggunakan skala Likert serta akan dihitung nilai EPIC Rate untuk mengetahui tingkat keefetivitasan media iklan game. Tahapan-tahapan penelitian multimedia dengan menggunakan model Villamil- Molina disajikan secara rinci pada Gambar diatas

3.1. Development

Tahapan ini adalah tahap pengembangan ide cerita serta konsep isi iklan game yang akan dituang ke dalam bentuk video iklan. Dalam tahapan ini dibagi menjadi 2 tahap, yaitu tahap pengembangan ide dan tahap pengembangan konsep yang akan dijelaskan sebagai berikut:

A. Pengembangan Ide

Tahap pengembangan ide ini dibuat berdasarkan ide yang sudah ada. Sebelumnya "Game Bisa Jadi” sudah terlebih dahulu dibuat oleh mahasiswa magang di Float Indonesia. Game yang dibuat untuk memperkenalkan karya mahasiswa ini adalah game berjenis game teka-teki dan game berbasis mobile android. Untuk membuat game ini lebih dikenal, maka terciptalah ide pembuatan video iklan game, yang berguna untuk memperkenalkan game kepada khalayak umum, dan berguna untuk memasarkan game lewat iklan game. Ide yang akan dibuat akan buat dalam bentuk video yang akan dipublikasikan di platform media online Instagram. Instagram menjadi salah satu platform yang akan digunakan untuk menjadi media iklan.

B. Konsep

Pada pembuatan video iklan game ini dilakukan dengan penggabungan antara video dengan animasi motion serta latar musik. Video yang menjelaskan tentang isi game yang akan dibuat menjadi iklan game ini dibuat dengan mengambil gambar dan scene latar orang yang sedang bermain game di mobile, untuk membuat video menjadi lebih menarik dan memberi kesan. Di dalam video juga akan dijelaskan tentang isi game, cara bermain dan penjelasan review game dengan tambahan motion, audio musik agar video menjadi lebih menarik. Setelah itu video akan diunggah ke platform media social Instagram dengan akun Float Indonesi

3.2. Pre Production

Tahapan ini merupakan tahapan selanjutnya setelah tahapan development selesai dikerjakan. Tahapan ini menjadi tahapan awal dalam perencanaan pembuatan video iklan game yaitu dengan membuat jadwal kerja sebagai acuan dalam pelaksanaan penelitian, narasi sebagai pedoman dalam melaksanakan produksi, dan pembuatan storyboard sebagai gambaran berupa scene dalam video. 
A. Narasi

Kegiatan yang dilakukan pada tahap ini adalah membuat naskah untuk video iklan game. Pada naskah ini berisikan alur dan isi cerita pada video iklan

Tabel 1 Naskah Video Iklan Game

\begin{tabular}{|c|c|c|c|}
\hline SCENE & SHOT & SCRIPT & VISUAL \\
\hline 1 & MS & $\begin{array}{l}\text { Muncul Logo game bisa } \\
\text { jadi }\end{array}$ & Sound effect \\
\hline 2 & MS & Muncul logo float.id & $\begin{array}{l}\text { Insert Slide: } \\
\text { Sound effect }\end{array}$ \\
\hline 3 & MS & $\begin{array}{l}\text { Seorang mahasiswa } \\
\text { sedang berjalan. Dan } \\
\text { menemukan } 2 \text { mahasiswa } \\
\text { lain sedang } \\
\text { berdiskusi }\end{array}$ & $\begin{array}{l}\text { Insert Motion Text: } \\
\text { Mahasiswa1: sedang } \\
\text { apa mereka } \\
\text { Mahasiswa } 2 \text { dan } \\
\text { 3: "ayo tebak" }\end{array}$ \\
\hline 4 & MS & $\begin{array}{l}\text { Mahasiswa } 1 \\
\text { mengeluarkan hp lalu } \\
\text { membuka game yang } \\
\text { pernah dia buat }\end{array}$ & $\begin{array}{l}\text { Insert Motion Text } \\
\text { dan Gambar: }\end{array}$ \\
\hline
\end{tabular}

B. Storyboard

Pada tahap ini adalah pembuatan storyboard yang dirancang untuk pembuatan video iklan game bisa jadi. Berikut beberapa scene storyboard yang direncanakan terdapat pada Gambar 2 .

\begin{tabular}{|c|c|c|}
\hline Scene & Sketsa & Keterangan \\
\hline \multirow{6}{*}{1} & \multirow{6}{*}{$\begin{array}{l}\text { Logo } \\
\text { Loat Id }\end{array}$} & Durasi: 5 detik \\
\hline & & Shot Size: MS \\
\hline & & Angle Cam: Center \\
\hline & & Aludio: music mp3 \\
\hline & & Dialog:- \\
\hline & & Ket: logo \\
\hline
\end{tabular}

Gambar 2. Desain Storyboard

C. Perangkat Lunak dan Perangkat Keras

Tabel 2. Software dan Hardware

\begin{tabular}{|c|c|}
\hline \multirow{2}{*}{ Jenis perangkat } & Keterangan \\
\hline Software & Adobe Premiere Pro CS6 \\
\cline { 2 - 2 } & Adobe After Effect CS6 \\
\cline { 2 - 2 } & Adobe Premiere Pro CS6 \\
\hline hardware & Kamera \\
\cline { 2 - 2 } & Laptop \\
\cline { 2 - 2 } & Harddisk 1 TB \\
\hline
\end{tabular}


3.3. Production

Pada proses yang dilakukan pada tahap ini adalah dengan melakukan shooting terlebih dahulu untuk pengambilan scene yang akan di edit menjadi sebuah video iklan dengan tambahan efek animasi dan motion, setelah itu proses pemilihan audio,dubbing,editing dan rendering video hingga menjadi sebuah produk jadi yaitu video iklan game yang diimplementasikan sebagai media iklan. Lalu video akan di unggah ke Instagram float Indonesia untuk menjadi iklan game, yang sudah terlebih dahulu dibuat akun Instagram nya yaitu akun Float Indonesia. Dan tahap production ini akan dibahas pada BAB IV

3.4. Postproduction

Pada proses yang dilakukan pada tahap ini yaitu tahap pengujian yang menggunakan teknik alpha testing dan beta testing, lalu dengan pengujian media analysis dan pengumpulan data menggunakan Epic model. Target responden merupakan pengguna Instagram, setidaknya 30 orang responden masyarakat Batam dan luar Batam yang menggunakan media online yaitu platform media social Instagram atau user pengguna Instagram dengan meliputi umur pengguna Instagram yaitu dengan rentang usia 13-44 tahun. Dalam penelitian ini akan dilakukan pengumpulan data melalui insight Instagram terlebih dahulu setelah itu user yang sudah melihat iklan akan mengisi kuesioner yang sudah di lampirkan di profile atau bio Instagram Float Indonesia lalu akan diambil data melalui kuesioner.

Jumlah sampel lebih dari 30 dan kurang dari 500 adalah tepat untuk kebanyakan penelitian (Suryani dkk, 2015). Pengujian akan dilakukan pada pengujian alpha dan pengujian beta. Berikut merupakan tahapan Post-Production:

A. Alpha Testing

Pengujian alpha merupakan tahapan melakukan uji kelayakan produk terhadap para ahli untuk mengetahui kualitas produk (Hendrayadi, 2017). Pengujian alpha dilakukan untuk menguji kelayakan produk melalui kuesioner online yang dilakukan oleh para ahli dan pengembang sehingga dapat diketahui segala kekurangan bahkan saran dalam proses pembuatan videoiklan Game. Untuk pembuatan Iklan Game yang efektif menurut Krasner (2008) diperlukan beberapa pertimbangan diantaranya Spatial, Temporal, Live Action, dan Typography. Dan akan dilakukan uji validitas dan uji reliabilitas terlebih dahulu.

1. Uji Validitas

Pada uji validitas ini taraf signifikansi uji validitas yang pakai pada penelitian ini adalah sebesar $5 \%$ atau 0,05 . Untuk jumlah sampel 30 orang responden dan taraf signifikansi yang digunakan adalah sebesar 5\% maka nilai r-hitung yang diperoleh harus lebih besar dari rtabel yaitu 0,361. Apabila nilai r-hitung lebih kecil dari 0,361 maka butir pertanyaan/pernyataan tersebut tidak valid. Tahap ini akan dibahas secara lengkap pada BAB 4.

2. Uji Reliabilitas

Selanjutnya setelah ditentukan tingkat kevalidan dari setiap butir yang terdapat di dalam kuesioner, selanjutnya yang dilakukan adalah uji reliabilitas. Tahap ini akan dibahas secara lengkap pada BAB 4.

B. Beta Testing

Setelah melakukan alpha testing tahap berikutnya adalah beta testing. Beta testing merupakan tahapan pengujian terakhir. Sebelum itu dilakukan pengujian dan pengambilan data pada Instagram dengan melihat insight Instagram setelah itu data diambil dari pengisian kuesioner oleh user pengguna Instagram yang sudah melihat Iklan Game di akun Instagram Float Id. Kuesioner akan diletakkan di profil dan bio Instagram. Pada beta testing akan dilakukan analisis efektivitas engan menggunakan metode EPIC Model. 4 Dimensi yang terdapat pada EPIC Model akan dicari nilainya masing-masing dan dianalisis untuk mengetahui apakah Iklan Game di Instagram efektif atau tidak.

\subsection{Analisis Kuesioner}

Efektivitas sebuah media iklan yang berpengaruh dapat diukur melalui EPIC Model yang dikembangkan oleh AC Nielsen, salah satu perusahan yang bergerak dibidang informasi global serta sebagai media dalam peneliti pemasaran terkemuka di dunia (Durianto dkk, 2008) mencakup empat dimensi atau aspek kritis, yakni : empati, persuasi, dampak dan komunikasi (Empathy, Persuation, Impact and Communication). Kuesioner dari penelitian Tugas Akhir ini mengacu pada jurnal Attar Asmawan (2013) tentang Analisis media iklan sebagai referensi aspek kuesioner. 


\begin{tabular}{|c|c|c|c|c|c|c|}
\hline No & Pertanyaan & $\begin{array}{l}\text { Sangat } \\
\text { Setuju }\end{array}$ & Setuju & Cukup & $\begin{array}{c}\text { Tidak } \\
\text { Setuju }\end{array}$ & $\begin{array}{l}\text { Sangat } \\
\text { Tidak } \\
\text { Setuju }\end{array}$ \\
\hline & \multicolumn{6}{|c|}{ Empathy (empati) } \\
\hline \multirow[t]{4}{*}{1} & $\begin{array}{l}\text { Apakah menurut anda Iklan } \\
\text { Game Bisa Jadi di Instagram } \\
\text { telah berjalan dengan baik }\end{array}$ & & & & & \\
\hline & $\begin{array}{l}\text { Apakah anda menyukai Iklan } \\
\text { Game "Bisa Jadi" yang ada di } \\
\text { Instagram Float Id }\end{array}$ & & & & & \\
\hline & $\begin{array}{l}\text { Apa anda setuju iklan Game } \\
\text { "Bisa Jadi" menjadi lebih } \\
\text { menarik dengan adanya iklan } \\
\text { yg di letak di IG story,IG } \\
\text { Feed, dan IG TV }\end{array}$ & & & & & \\
\hline & \multicolumn{6}{|c|}{$\begin{array}{ll} & \text { Persuation (Persuasi) }\end{array}$} \\
\hline \multirow[t]{3}{*}{2} & $\begin{array}{l}\text { Setujukah anda Iklan Game } \\
\text { "Bisa Jadi" di instagram } \\
\text { mempunyai daya Tarik tinggi }\end{array}$ & & & & & \\
\hline & $\begin{array}{l}\text { Setelah melihat iklan Game } \\
\text { "Bisa Jadi" di Instagram } \\
\text { mendorong anda untuk } \\
\text { mengajak teman anda untuk } \\
\text { melihat Iklan dan } \\
\text { mendonwload Game tersebut }\end{array}$ & & & & & \\
\hline & \multicolumn{6}{|c|}{ Impact (Dampak) } \\
\hline \multirow[t]{3}{*}{3} & $\begin{array}{l}\text { setelah melihat iklan Game } \\
\text { "Bisa Jadi" yang ada di IG } \\
\text { story dan IG feed anda } \\
\text { tertarik untuk melihat Info } \\
\text { iklan lebih lengkapya diIGTV }\end{array}$ & & & & & \\
\hline & $\begin{array}{l}\text { Apakah Anda mengetahui dan } \\
\text { mengenal Game "Bisa Jadi" } \\
\text { setelah anda melihat iklan } \\
\text { Game yang ada di Instagram } \\
\text { Float Id }\end{array}$ & & & & & \\
\hline & \multicolumn{6}{|c|}{ Communication } \\
\hline \multirow[t]{3}{*}{4} & $\begin{array}{l}\text { Apakah Iklan Game "Bisa } \\
\text { Jadi" yang anda lihat di IG } \\
\text { Feed dan IGTV sudah } \\
\text { menyampaikan pesan dengan } \\
\text { jelas }\end{array}$ & & & & & \\
\hline & $\begin{array}{l}\text { Apakah Iklan Game "Bisa } \\
\text { Jadi" di IG Feed Float Id lebih } \\
\text { menarik daripada Iklan Game } \\
\text { di IG TV }\end{array}$ & & & & & \\
\hline & \begin{tabular}{l}
\multicolumn{3}{l}{ Dari Iklan Game "Bisa jadi" di } \\
Instagram sudah jelas \\
memaparkan fungsi, manfaat, \\
dan alasan \\
mendonwload Game "Bisa \\
jadi"
\end{tabular} & & & & & \\
\hline
\end{tabular}


4. HASIL DAN PEMBAHASAN

4.1. Production

Di tahap ini merupakan tahap pembuatan iklan game menggunakan aplikasi Adobe Illustrator CS6, Adobe Premiere Pro CS6, dan Adobe After Effects CS6. Kegiatan yang akan dilakukan pada tahapan ini adalah Tracing and Colouring, Animating, Dubbing, Editing, dan Rendering.

A. Tracing and Colouring

Proses yang dilakukan pada tahap ini adalah membuat objek-objek dari sketsa yang telah dibuat kedalam bentuk digital menggunakan aplikasi Adobe Illustrator CS6. Cara melakukan Tracing and Colouring akan di tunjukkan pada tabel 4.1 Proses Tracing and Colouring dan hasil dari beberapa objek yang akan digunakan di dalam motion graphic akan di tunjukkan pada tabel 4.2 Tracing and Colouring.

Tabel 4. Tracing and Colouring

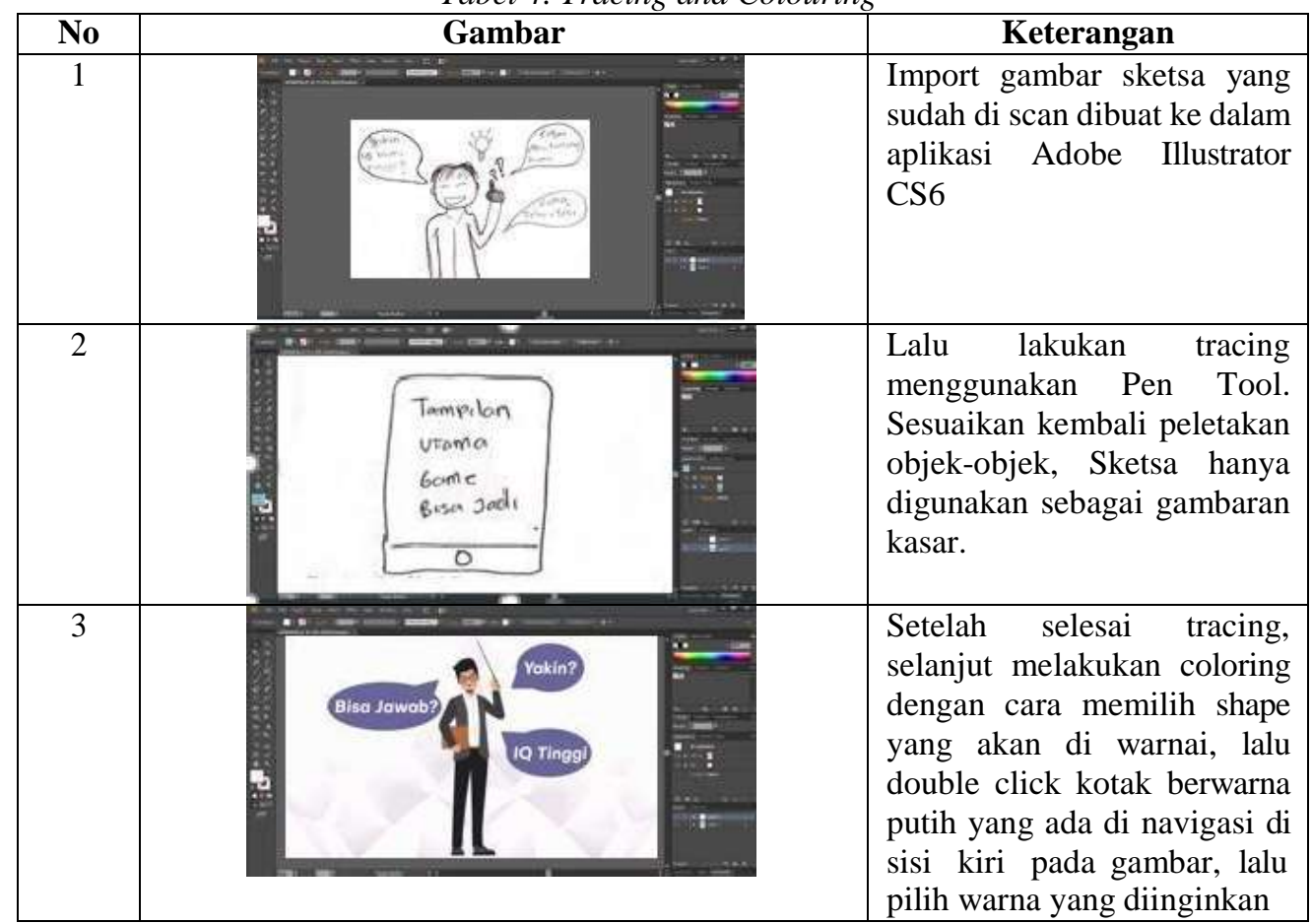

Tabel 5. Hasil Tracing and Coloring

\begin{tabular}{|l|c|c|}
\hline No & Sketsa & Hasil Tracing and Coloring \\
\hline 1 & &
\end{tabular}


B. Dubbing

Pada tahap dubbing, yang dilakukan adalah merekam suara manusia yang akan diletak didalam video untuk membantu menjelaskan isi dari video Iklan yang dibuat. Pada penilitian ini, dubbing dilakukan dengan mengisi suara oleh penulis.

C. Animating

Setelah melalui tahap Tracing and Colouring, selanjutnya merupakan tahap Animating. Di tahap ini objek-objek dari hasil Tracing akan di animasikan menggunakan aplikasi Adobe After Effects CS6. Efek-efek visual yang diberikan pada objek yaitu mengubah Scale, Rotation, Position, dan Opacity. Di dalam penelitian ini juga menggunakan teknik 3D Movement Camera. 3D Movement Camera merupakan salah satu fitur yang ada di dalam Adobe After Effect CS6. Cara menggunakan Camera di Adobe After Effect CS6 yaitu dengan mengklik Layer lalu pilih New lalu pilih Camera, atur settingan kamera sesuai kebutuhan

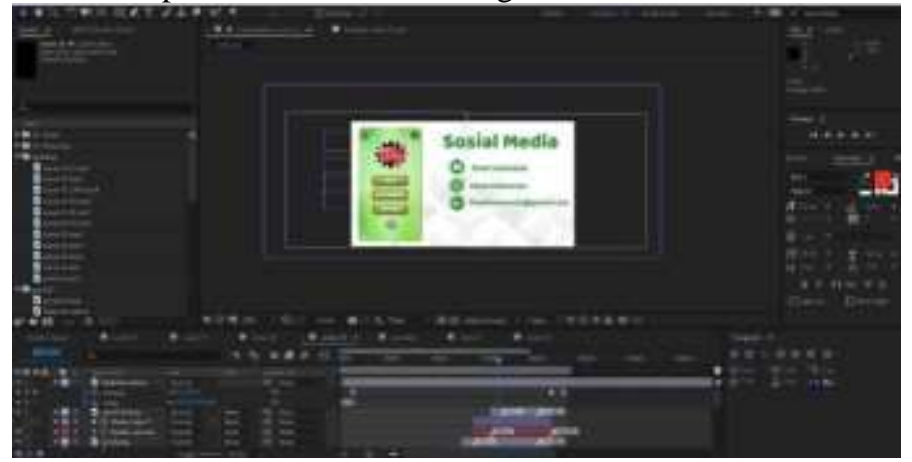

Gambar 3. Animating

D. Editing

Setelah selesai Animating, selanjutnya yang dilakukan adalah editing. Pada tahap ini yang dilakukan adalah menggabungkan Audio dan Animasi yang sudah dibuat menjadi sebuah video iklan. Software yang digunakan ditahap ini adalah Adobe Premier Pro CS6.

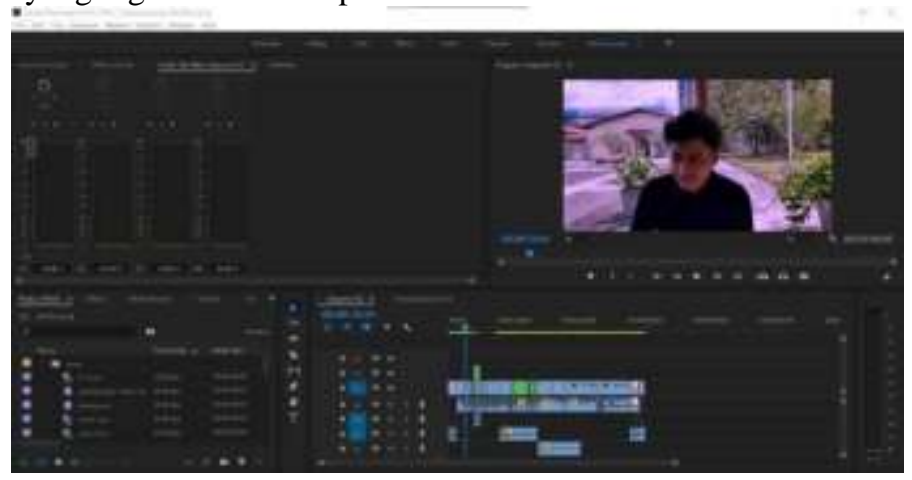

Gambar 4. Editing

E. Rendering

Tahap ini meruakan tahap terakhir dari proses produksi, yaitu Rendering. Rendering dilakukan setelah tahap Editing selesai, lalu akan dilakukan Render dengan menggunakan Software yang sama yaitu Adobe Premiere Pro CS6.

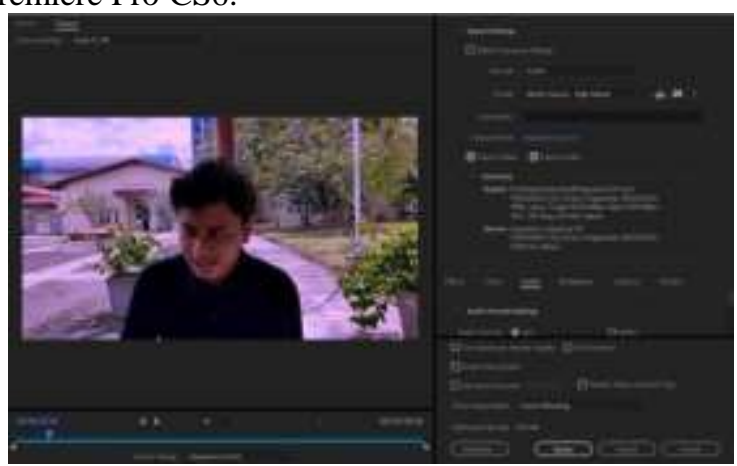

Gambar 5. Rendering 
4.2. Postproduction

Pada tahap ini akan dilakukan dua tahapan pengujian yaitu yang pertama adalah alpha testing dan yang kedua adalah beta testing. Alpha testing ditujukan untuk menguji tingkat kevalidan dan juga menguji reliabilitas dari instrumen yang digunakan pada penelitian ini. Selanjutnya pada beta testing, yang dilakukan adalah pengambilan data terlebih dahulu dengan media analysis, melihat Insight Iklan Game pada Instagram Float Id. Berdasarkan berapa view video iklan di Float Id yang sudah dilihat oleh user pengguna Instagram akan mempengaruhi berapa orang yang akan mengisi Kuesioner. Kuesioner akan dijadikan link di bio atau profil pada Instagram Float Id melalui media online yaitu Google Form. Link Kuesioner akan dapat diakses oleh user Instagram yang sudah melihat video iklan game "Bisa Jadi" di feed/InstagramTV dengan target responden masyarakat umum pengguna Instagram yang ada di Batam ataupun luar Batam dengan umur 13-40 tahun.

A. Alpha Testing

Pengujian ini dilakukan oleh Pengembang game dan pakar multimedia yang ada di start up Float Indonesia dan dosen yang bersangkutan pada prduk, dengan tujuan agar produk yang dihasilkan jika terjadi kesalahan atau kekurangan dapat di perbaiki. Langkah pengujian ini dilakukan dengan mengisi kuesioner dengan pernyataan seputar Spatial, Temporal, Live Action, dan Typography. Kemudian setelah mengumpulkan data kuesioner, setelah itu akan dilanjutkan dengan perhitungan Pada alpha testing, penulis akan melakukan 2 buah pengujian kuesioner yang akan digunakan sebagai alat ukur, yaitu uji validitas dan uji reliabilitas.

1. Uji Validitas

Setelah mengambil data dari kuesioner oleh ahli dan pengembang game pada vido iklan game akan dilakukan perhitungan uji validitas yang penulis lakukan menggunakan bantuan aplikasi IBM SPSS Statistic 25. Setelah didapat nilai korelasi (r-hitung), selanjutnya adalah membandingkan nilai r-hitung dengan nilai r-tabel untuk menentukan apakah setiap butir yang ada di dalam kuesioner valid atau tidak valid, seperti ditunjukkan pada Tabel 4.4 Hasil uji validitas berikut :

Tabel 6. Hasil Uji Validitas

\begin{tabular}{|c|c|c|c|}
\hline No.Item & r-hitung & r-tabel $(\boldsymbol{\alpha}=\mathbf{0 , 0 5})$ & Hasil \\
\hline 1 & 0,879 & 0,361 & Valid \\
2 & 0,866 & 0,361 & Valid \\
3 & 0,870 & 0,361 & Valid \\
4 & 0,845 & 0,361 & Valid \\
5 & 0,838 & 0,361 & Valid \\
6 & 0,893 & 0,361 & Valid \\
7 & 0,778 & 0,361 & Valid \\
8 & 0,860 & 0,361 & Valid \\
9 & 0,848 & 0,361 & Valid \\
10 & 0,873 & 0,361 & Valid \\
\hline
\end{tabular}

2. Uji Reliabilitas

Setelah hasil uji validitas didapat, selanjutnya adalah mengetahui nilai dari uji reliabilitas Cronbach's Alpha. Pengukuran uji reliabilitas pada penelitian ini menggunakan aplikasi IBM SPSS Statistic 25. Setelah didapat nilai Alpha Cronbach, selanjutnya adalah menentukan apakah kuesioner yang digunakan reliabel atau tidak dengan membandingkan nilai yang didapat. Apabila nilai Alpha Cronbach lebih dari 0,6 maka kuesioner yang digunakan reliabel, Tabel 7. Hasil Uji Reliabilitas

\begin{tabular}{|c|c|c|}
\hline Cronbach's Alpha & N of Items & Hasil \\
\hline 0,787 & 11 & Reliabel \\
\hline
\end{tabular}

Dari pengujian alpha testing yang sudah dilakukan, dapat diambil kesimpulan bahwa setiap butir pernyataan yang ada di dalam kuesioner sudah valid dengan masing-masing skor r-hitung lebih besar dari r-tabel dan kuesioner yang digunakan reliabel dengan skor Alpha Cronbach yang didapat lebih besar dari 0,6 


\section{B. Beta Testing}

Pengujian Beta dilakukan terhadap responden di Instagram khususnya gamers, game developer ataupun masyarakat umum sebagai user pengguna Instagram. Produk yang telah melewati pengujian alpha akan dilanjutkan dengan pengujian beta untuk mengetahui efektivitas sebuah iklan game yang di iklankan di platform Instagram. Yaitu iklan Game "Bisa Jadi" yang ada di Instagram Float Id. Yaitu iklan Game "Bisa Jadi" yang ada di Instagram Float Id. Pada tahap ini dilakukan media analysis pada Instagram Float Indonesia. Tahap pertama yaitu dengan melihat insight iklan game "bisa jadi" pada Instagram Float Indonesia. Pada insight yang didapatkan dengan berapa banyak view setelah itu melihat data kefektivitasan melalui pengumpulan data di kuesioner.

Media analisys

Media analysis merupakan tahapan pertama untuk analisa efektivitas penggunaan social media Instagram Float Indonesia. Tahapan ini dilakukan untuk mengukur kinerja dan keefektivitasan iklan game "bisa jadi” pada akun Instagram Float indonesia. Dalam tahapan ini dilakukan dengan matriks, yaitu reach analysis. Dengan

Mengetahui seberapa besar jangkauan dari Instagram Float Indonesia melalui data total followers yang dapat diakses melalui Instagram Insight yang terdapat di dalam profil Instagram Float Indonesia. Followers merupakan total pengikut dari sebuah akun Instagram. Terdapat 421 followers Float Indonesia (diakses pada tanggal 24 Agustus 2020). Dengan view yang didapat dari Iklan game di Instagram Feed adalah sebanyak 115 View dan Pada Instagram Tv sebanyak 86 view. Pada reach analisis akan dilakukan analisa reach dan impresi. Dalam Instagram juga terdapat fitur insight yang dapat melihat reach dan impressi. Reach Instagram juga sangat berguna untuk menyusun strategi pemasaran produk video iklan game yang ada di Instagram. Pengaruh reach Instagram antara lain meningkatkan strategi pemasaran game dan video iklan game, seperti brand awareness, penambahan audiens, ikatan audiens dengan brand, dan mengetahui efektivitas konten video iklan. Setelah itu Hasil viewers pada iklan game di Instagram ditunjukan pada gambar 4.4 .

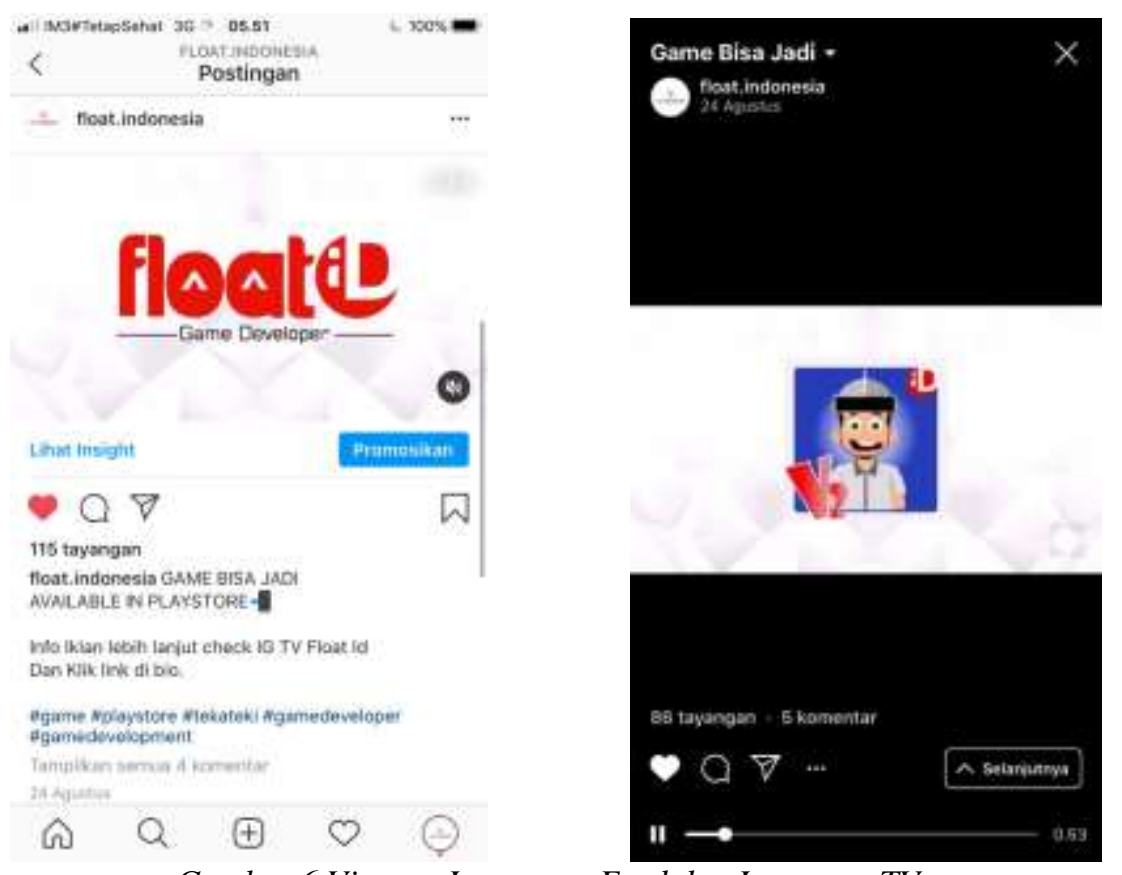

Gambar 6 Viewers Instagram Feed dan InstagramTV

Maka dengan melihat hasil viewers yang didapat, Instagram feed diketahui lebih banyak mendapatkan view dibanding Instagram TV, dengan begitu video iklan game "Bisa Jadi" di Instagram feed lebih berpengaruh dalam menarik minat pengguna Instagram. Menarik dan berepengaruh nya dapat dilihat dengan setelah melihat insight reach dan impresi pada feed video iklan game bisa jadi, user pengguna Instagram dan gamers akan langsung mencoba untuk mengunduh game bisa jadi setelah melihat video iklan game bisa jadi di Instagram. Selain itu dari data insight Instagram, terlihat dalam video yang diletakan di feed Instagram Float id, banyak pengguna Instagram yang mennge-share kembali video iklan game bisa jadi kepada user pengguna Instagram. Maka ini menimbulkan ketertarikan user pengguna Instagram dan masyarakat untuk melihat video iklan game bisa jadi dan mengunduh game bisa jadi. Selain itu 
video iklan game bisa jadi berpengaruh menambah audiens dengan terlihatnya penambahan followers di Instagram setelah itu dapat meningkatkan nilai brand dan pemasaran video iklan game bisa jadi. Untuk prefensi menarik nya video iklan game bisa jadi ini dapat dilihat dengan adanya daya tarik orang-orang untuk membuat konten ataupun video iklan yang sama seperti video iklan game bisa jadi, maka dapat disimpulkan video iklan game bisa jadi yang ada di Instagram dapat menarik minat dan menginspirasi user pengguna Instagram yang ingin membuat video iklan game ataupun membuat game setelah melihat video iklan game bisa jadi di Instagram Float.id

1. Hasil Analisis EPIC Model

Hasil pengumpulan data yang telah dilakukan melalui kuesioner online terhadap 45 responden pengguna Instagram yang sudah melihat iklan game "bisa jadi” di Instagram Float indonesia akan diuraikan dan perhitungan terhadap empat dimensi EPIC Model yang menjadi parameter pengukuran efektivitas media iklan game dalam bentuk video dengan penilaian EPIC Model yakni empati, persuasi, dampak dan komunikasi (Empathy, Persuation, Impact dan Communication). Berikut uraian masing-masing dimensi serta hasil perhitungan:

a. Dimensi Empati

Hasil nilai pada masing-masing dimensi Empathy akan dihitung kembali untuk megetahui tingkat efektivitas dimensi Empathy (E). Berikut skor komulatif rata-rata dimensi Empathy (E).

$$
\mathrm{XEmpathy}(\mathrm{E})=\frac{4,17+4,17+4,42}{3} \quad \frac{12,76}{3}==4,25
$$

Hasil analisis penelitian pengukuran efektivitas media iklan game berdasarkan EPIC Model untuk dimensi Empathy mendapatkan nilai rata-rata 4,25 sehingga nilai Empathy menempatkan rentang penilaian sangat efektif. Hal ini menunjukan bahwa iklan game "bisa jadi" di instagram dianggap menarik dan mudah diingat.

b. Dimensi Persuasi

Hasil nilai pada masing-masing dimensi Persuation akan dihitung kembali untuk megetahui tingkat efektivitas dimensi Persuation $(\mathrm{P})$. Berikut skor komulatif rata-rata dimensi Persuation $(\mathrm{P})$.

$$
\mathrm{XPersuation}(\mathrm{P})=\frac{4,2+4,17}{2} \quad \frac{8,3}{2}=4,15
$$

Hasil analisis penelitian pengukuran efektivitas iklan game berdasarkan EPIC Model untuk dimensi Persuation mendapatkan nilai rata-rata 4,15 sehingga nilai Persuation menempatkan rentang penilaian sangat efektif. Hal ini menunjukan bahwa media iklan game dianggap memberikan kepercayaan

c. Dimensi Dampak

Hasil nilai pada masing-masing dimensi Impact akan dihitung kembali untuk megetahui tingkat efektivitas dimensi Impact (I). Berikut skor komulatif rata-rata dimensi Impact (I).

$$
\mathrm{X} \operatorname{Impact}(\mathrm{I})=\frac{4,15+4,24}{2} \quad \frac{8,39}{2}=4,19
$$

Hasil analisis penelitian pengukuran efektivitas iklan game di Instagram berdasarkan EPIC Model untuk dimensi Impact mendapatkan nilai rata-rata 4,19 sehingga nilai Impact menempatkan rentang penilaian efektif. Hal ini menunjukan bahwa iklan game di instagram dianggap berhasil mengenalkan game "bisa jadi “ 
d. Dimensi Komunikasi

hasil nilai pada masing-masing dimensi Communcation akan dihitung kembali untuk megetahui tingkat efektivitas dimensi Communication (C).

$$
\mathrm{X} \text { Communcation }(\mathrm{C})=\frac{4,2+4,33+4.26}{3} \quad \frac{12,79}{3}==4,26
$$

Hasil analisis penelitian pengukuran efektivitas iklan game di instagram. berdasarkan EPIC Model untuk dimensi Communcation mendapatkan nilai rata-rata 4,26 sehingga nilai Communcation menempatkan rentang penilaian sangat efektif. Hal ini menunjukan bahwa iklan game "bisa jadi" dianggap berhasil memaparkan informasi mengenai game bisaa jadi sehingga mudah dimengerti dan menarik minat untuk mendonwload game lewat iklan game di instagram.

Dari hasil perhitungan pengukuran efektivitas iklan game sebagai media iklan game. Melalui EPIC Model (Empathy, Persuation, Impact and Communication) maka didapatlah sebuah grafik. secara keseluruhan dapat dilihat pada gambar 6 .

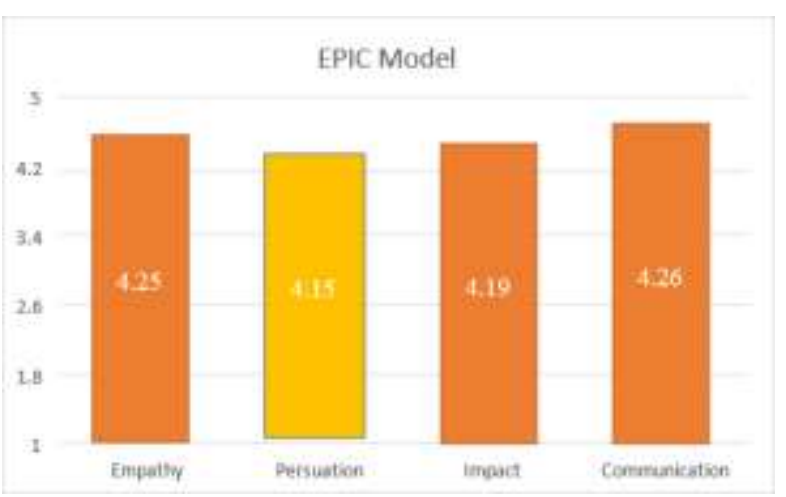

Gambar 6. Hasil EPIC Model

\section{KESIMPULAN}

Berdasarkan pengujian dan analisis yang telah dilaksanakan, maka di dapatkan beberapa kesimpulan, yakni :

1. Pembuatan video iklan game sebagai media iklan online menerapakan metode pengembangan Vilamill-molina dengan hasil berupa video format MP4 berdurasi 1-3 menit. Video iklan dibuat dalam gabungan scene dan motion. Untuk penyampain informasi Iklan Game "Bisa Jadi" di Instagram.

2. Analisa iklan game "Bisa Jadi" di Float Indonesia melalui insight didapatkan hasil viewers pada Instagram Feed sebanyak 115 view dan pada Instagram TV sebanyak 86 view dan perbandingan antara kedua fitur Instagram didapatkan lebih banyak viewers Instagram Feed, maka Iklan game "Bisa Jadi" di Instagram Feed lebih berpengaruh dalam penerapan video iklan game berbasis Instagram.

3. Dari data statistik akun Instagram Float Id, follower yang didapat setelah di unggah nya video iklan game bisa jadi ke Instagram Float Id adalah sebanyak 421 Followers, dari hanya 2 followers sebelum di uploud nya video iklan game bisa jadi. Maka followers Instagram Float Indonesia mengalami kenaikan ikan kurang lebih 400 follower di beberapa minggu dan bulan setelah di unggah nya video iklan game di Instagram feed dan Instagram TV.

4. Video Iklan game "Bisa Jadi" juga diukur keefektivitasan nya dengan metode penelitian Epic Model melalui Kuesioner online. Viewers Instagram mempengaruhi jumlah responden pengisi kuesioner dan didapatkkan data dari 45 orang responden pengguna Instagram. Jadi melalui EPIC Model dinyatakan iklan game berbasis Instagram sangat efektif berdasarkan hasil perhitungan empat dimensi diantaranya yakni Empathy 4,25, Persuation 4,15, Impact 4,19 dan Communication 4,26. 


\section{DAFTAR PUSTAKA}

[1] Adhiazni, Viranda(2019) Pemanfaatan Social Media Analytics Pada Instagram Dalam peningkatan Efektivitas Pemasaran. Jakarta: UIN

[2] Asmawan, Attar (2013). Analisis Efektivitas Iklan Televisi Produk So Good Versi. Bogor: Alfabeta.

[3] Binanto, I. (2013). Perbandingan Metode Pengembangan Perangkat Lunak Multimedia. In Prosiding Seminar RiTekTra 2013. Teknik Informatika, Fakultas Sains dan Teknologi. Universitas Sanata Dharma.

[4] Djamarah, S.B. dan Zain, A. (2010) Strategi Belajar Mengajar. Jakarta: PT Rineka Cipta.

[5] Effendy, H. (2002). Mari Membuat Film: Panduan Menjadi Produser. Yogyakarta: Panduan.

[6] Komputer, Wahana. 2010. Panduan Praktis Pinnacle 12 untuk Pengolahan Video. Yogyakarta: Andi

[7] Munadi, Y. (2008). Media Audio Visual. Sebuah Pendekatan Baru. Ciputat: Gaung Persada Press.

[8] Munir. (2012). Multimedia Konsep \& Aplikasi dalam Pendidikan. Bandung: Alfabeta.

[9] Narita, T., Suyanto, A. 2019, ANALISA EFEKTIVITAS IKLAN WEB SERIES DENGAN MENGGUNAKAN EPIC MODEL, Jurnal Mitra Manajemen, 3(1), 84-95.

[10] Rayner, K., and Castelhano, M. S. (2008). "Eye movements during reading, scene perception, visual search, and while looking at print advertisements," in Visual Marketing. From Attention to Action, eds M. Wedel and R. Pieters (New York: Lawrence Erlbaum), 9-42.

[11] Sanjaya, W. (2010). Strategi Pembelajaran Berorientasi Standar Proses Pendidikan. Jakarta: Kencana.

[12] Sidiq, Anwar (2017) PEMANFAATAN INSTAGRAM SEBAGAI MEDIA DAKWAH (STUDY AKUN @fuadbakh). Undergraduate thesis, UIN Raden Intan Lampung

[13] Sugiarti, E. (2014). Perancangan Iklan Komersial Untuk TV lokal Menggunakan Animasi Motion Graphics Pada Kedai Djong Java. Skripsi, Sekolah Tinggi Manajemen Informatika Komputer Yogyakarta.

[14] Sugiyono. (2017). Metode Penelitian Kuantitatif, Kualitatif, dan R\&D. Bandung: Alfabeta.

[15] Sutisno. (1993). Pedoman Praktis Penulisan Skenario Televisi dan Video. Jakarta: Gramedia.

[16] Wahana. (2010). Kolaborasi Adobe Premiere pro CS5 dan After Effect CS5. Semarang: ANDI.

[17] Hasanah, Nur (2015) Analisis Efektivitas Iklan Jejaring social sebagai Media Promosi Menggunakan EPIC Model. Jogja: UGM. 